\title{
A Chimeric Mouse Model of Gaucher Disease
}

\author{
Ernest Beutler, Carol West, Bruce E. Torbett, and Hiroshi Deguchi
}

The Scripps Research Institute, Department of Molecular and Experimental Medicine, La Jolla, California, USA

Contributed by E. Beutler. Accepted May 6, 2002

\begin{abstract}
Background: There is a major need for a mouse model of Gaucher disease, but the glucocerebrosidase knockout mouse is not viable; it dies shortly before or immediately after birth, apparently because of involvement of the central nervous system and/or skin. The most common form of Gaucher disease, type I, has a phenotype that is limited to the monocyte-macrophage system.

Materials and Methods: We have created a chimeric mouse by infusing hematopoietic stem cells from fetuses that are homozygous for the glucocerebrosidase knockout into irradiated mice.
\end{abstract}

Results: The chimeric mice manifested a severe deficiency of glucocerebrosidase activity in peripheral blood cells and spleen indicating a lack of cell-cell correction. Levels of glucocerebroside in spleen and liver are increased, and infusing the mice with exogenous glucocerebroside/albumin particles produced a marked increase in the amount of glucocerebroside stored in liver and spleen. Morphologically identifiable Gaucher cells were not present.

Conclusions: The chimeric model reflects the increased glycolipid storage in the reticuloendothelial system that is characteristic of Gaucher disease, and could be useful as a model for studying treatment of Gaucher disease.

\section{Introduction}

Gaucher disease is the most common glycolipid storage disorder (1). Caused by a deficiency of the lysosomal enzyme glucocerebrosidase, this disorder is characterized by an accumulation of the glycolipid glucocerebroside in macrophages throughout the body, particularly in spleen, liver, marrow, and bone. Treatment modalities have included replacement of the deficient enzyme (2), gene transfer into hematopoietic stem cells (3), and inhibition of the synthase that converts ceramide to glucosyl ceramide (glucocerebroside) $(4,5)$. The development of each of these treatment modalities has depended almost entirely on clinical trials because no animal model of the disease is available. Targeted disruption of the glucocerebrosidase gene is lethal at birth (6). Although this was at first thought to be due to the inadvertent disruption of the nearby metaxin gene, mutations introduced into glucocerebrosidase gene without disrupting metaxin also failed to produce surviving deficient mice (7). It is perhaps not surprising that mice would not be viable without glucocerebrosidase; the most common null mutation of humans, and insertion of a $G$ near the $5^{\prime}$ end of the coding sequence of the gene (8) seems to be lethal; no homozygote has ever been found. Other severely deficient mutants produce rapidly progressive fatal neurologic disease in humans, designated as type II disease (1). Thus, it was speculated

Correspondence should be addressed to: E. Beutler, The Scripps Research Institute, Department of Molecular and Experimental Medicine, 10550 North Torrey Pines Road, La Jolla, CA 92037. Phone: 858-784-8040; fax: 858-784-2083, e-mail: beutler@scripps.edu. by Tybulewicz et al. (6) that the early death of the homozygous knockout mice was the result of neuropathology and by Liu et al. (7) that death might be due to glucocerebroside-induced permeability of the skin. The much more common, milder human disease, type I or "adult" Gaucher disease, has a phenotype that is due almost entirely to involvement of macrophages, specifically without nervous system or skin involvement. Because macrophages are progeny of the hematopoietic stem cell, it seemed possible to produce a viable chimeric model of type I Gaucher disease in the mouse by transplanting hematopoietic stem cells from knockout fetuses to irradiated adults.

\section{Materials and Methods}

Mice

Mice heterozygous for targeted disruption of the glucocerebrosidase $(G b a)$ gene, originally produced by Tybulewicz et al. (6), were obtained from The Jackson Laboratory (Bar Harbor, ME, USA) (Strain name: B6.129S6-Gbatmi/Nsb $)$. They were backcrossed into the background strain C57BL/6J. Heterozygotes, identified by genetic analysis of their DNA, were bred and the pregnant females killed 1 or 2 days before term for isolation of fetal stem cells.

\section{Stem Cell Isolation}

Pregnant mice were killed and fetuses were removed with sterile precautions. The fetal liver was forced through a 70-micron nylon cell strainer into a $50 \mathrm{ml}$ sterile tube washed through the filter with $15 \mathrm{ml}$ of $50 \%$ FBS in RPMI. After centrifugation at $600 \mathrm{~g}$ for $10 \mathrm{~min}$, the supernatant was removed and 
the sedimented cells resuspended in $2 \mathrm{ml} 50 \%$ FBS, $10 \%$ dimethylsulfoxide (DMSO) in RPMI. Three-tenth-milliliter aliquots were placed into vials, surrounded with Styrofoam, and placed into a $-70^{\circ} \mathrm{C}$ freezer for $24-48 \mathrm{hr}$ and then into liquid nitrogen.

\section{Identification of Knockout Fetuses}

The DNA of the tails of each fetus was genotyped for the glucocerebroside gene pattern by PCR. A sense primer, MGC 9F, common to both the normal and knockout glucocerebrosidase DNA and anti-sense primers, MGC 10R, located in the deleted part of the knockout GC gene and NEO R2, found in the NEO portion of the knockout DNA were used in a multiplex PCR to amplify either the normal or the knockout DNA.

\section{MGC 9F CCTGAATCCTGAAGGAGGGC MGC 10R ATCCCTCGGGAATGAACTTGCT NEO R2 CTCAGCGGTGCTGTCCATC}

Each 50- $\mu$ L PCR reaction contained the following: $33.4 \mathrm{mM}$ TrisHCl pH 8.8, $8.3 \mathrm{mM}\left(\mathrm{NH}_{4}\right)_{2} \mathrm{SO}_{4}$, $3.35 \mathrm{mM} \mathrm{MgCl}, 85 \mu \mathrm{g} / \mathrm{ml}$ BSA, $800 \mathrm{ng}$ of primer MGC 9F, $200 \mathrm{ng}$ each of primers MGC 10R and NEO R2, 5\% DMSO, $0.2 \mathrm{mM}$ dATP, $0.2 \mathrm{mM}$ dGTP, $0.2 \mathrm{mM}$ dTTP, $0.2 \mathrm{mM}$ dCTP, $0.75 \mathrm{U}$ Taq polymerase, and 50-200 ng of mouse tail DNA. The reactions were denatured at $98^{\circ} \mathrm{C}$ for $4 \mathrm{~min}$ and amplified for 33 cycles of $94^{\circ} \mathrm{C}$ for $30 \mathrm{sec}, 61^{\circ} \mathrm{C}$ for $25 \mathrm{sec}$, and $72^{\circ} \mathrm{C}$ for $30 \mathrm{sec}$. On a $10 \%$ acrylamide gel, the amplified fragment sizes were 464 nucleotides (nt) for the normal GC band and 362 for the knockout band.

\section{Transplantation of Mice}

Glucocerebrosidase gene knockout fetal cells were incubated at $37^{\circ} \mathrm{C}$ until just thawed and transferred to $15-\mathrm{ml}$ sterile tubes. Ten milliliters of $37^{\circ} \mathrm{C}$ serum free media (Iscoves MDM with 10\% BIT 9500 serum free supplement and $5 \times 10^{-5} \mathrm{M} \beta$-mercaptoethanol, Stem Cell Technologies, Vancouver, BC, Canada) containing $50 \mathrm{U} / \mathrm{ml}$ DNase I was added slowly, the suspension was incubated for $10 \mathrm{~min}$ at $37^{\circ} \mathrm{C}$ and the centrifuged at $600 \mathrm{~g}$ for $10 \mathrm{~min}$. The supernatant was removed and the cells resuspended in $1 \mathrm{ml}$ serum free media. Ten $\mu \mathrm{L}$ of suspension was diluted with $90 \mu \mathrm{l}$ of $0.4 \%$ trypan blue and the viable cells counted in a hemocytometer. A volume of suspension containing $0.5 \times 10^{6}$ viable cells was diluted into $0.3 \mathrm{ml}$ saline just before infusion. Mice were irradiated (Model 143-35DM, J.L. Shephard and Associates, San Fernando, CA, USA) with two doses of $600 \mathrm{cG} 2 \mathrm{hr}$ apart and within the next hour injected through the tail vein with $0.5 \times 10^{6}$ knockout fetal liver cells. After transplantation, mice were maintained in sterile cages with a normal diet and on water containing $100 \mathrm{mg} / \mathrm{L}$ neomycin sulfate and $13 \mathrm{mg} / \mathrm{L}$ polymyxin B sulfate for 3 weeks.

\section{Acid $\beta$-Glucosidase Assay}

Acid $\beta$-glucosidase (glucocerebrosidase) activity was assayed using 4-methylumbelliferone as the substrate (9).

\section{Extraction of Glycolipids From Liver and Spleen}

Mice were euthanized with halothane and the spleens and livers were removed; 0.2- to 0.3 -g slices were transferred to 2-ml glass homogenizers and sonicated for $10 \mathrm{~min}$ or homogenized with $0.6-0.8 \mathrm{ml}$ of 2:1 chloroform/methanol until the solution appeared uniform. After addition of $0.12 \mathrm{ml} \mathrm{H}_{2} \mathrm{O}$, the homogenate was vortexed and centrifuged at $10,000 \mathrm{~g}$ for $5 \mathrm{~min}$ at room temperature. The clear lower layer was removed to a glass tube and allowed to evaporate overnight. The samples are capped and stored at $-70^{\circ} \mathrm{C}$ until analysis.

\section{Analysis of Glucocerebroside Concentration}

Glucocerebroside in chloroform/methanol extracts was quantitated using a Waters high performance liquid chromatography (HPLC) system (Waters Corp., Milford, MA, USA) coupled to a Sedex-55 evaporative light scattering detector system (ELSD) (SEDERE, Vitry sur Seine, France) as previously described (10), using a $\mu$ Porosil column $(300 \times 3.9$ $\mathrm{mm}$ ) with isocratic chloroform/methanol/0.5\% TFA/water (79:19:1:1). Under these conditions, purified reference glucocerebroside (human spleen, Sigma, St Louis, MO, USA) shows one peak eluting at $4.1 \mathrm{~min}$. To quantify glucocerebroside, a calibration curve was made by analyzing varying amounts of reference glucocerebroside and the standard curve can be fit by a logarithmic curve based on the equation

Peak area $=2.37 \times 10^{6} \times[\text { Glucocerebroside }(\mu \mathrm{g})]^{1.73}$

covering the range $0.1-2.0 \mu \mathrm{g}$ glucocerebroside.

\section{Albumin-Glucocerebroside (GC/Alb) Particles}

Glucocerebroside was precipitated on albumin particles using the method of Barton and Rosenberg (11). Five milligrams of glucocerebrosides from human spleen (Sigma-Aldrich, St. Louis, MO, USA) are dissolved in $1 \mathrm{ml}$ of hot $\left(60-65^{\circ} \mathrm{C}\right)$ methanol and added slowly to $2 \mathrm{ml}$ of BSA (fatty acid free), $12.5 \mathrm{mg} / \mathrm{ml}$, with constant stirring. The resulting milky precipitate was dialyzed against several changes of $1 \mathrm{~L}$ of sterile saline at $4^{\circ} \mathrm{C}$. If upon microscopic examination the precipitate appeared clumped, the clumps were broken by sonication, three or four 2-second bursts of 9 amps.

\section{Results}

The glucocerebrosidase activity in the spleen and peripheral blood leukocytes of mice transplanted with homozygous knockout (enzyme deficient) hematopoietic stem cells and control mice transplanted with 

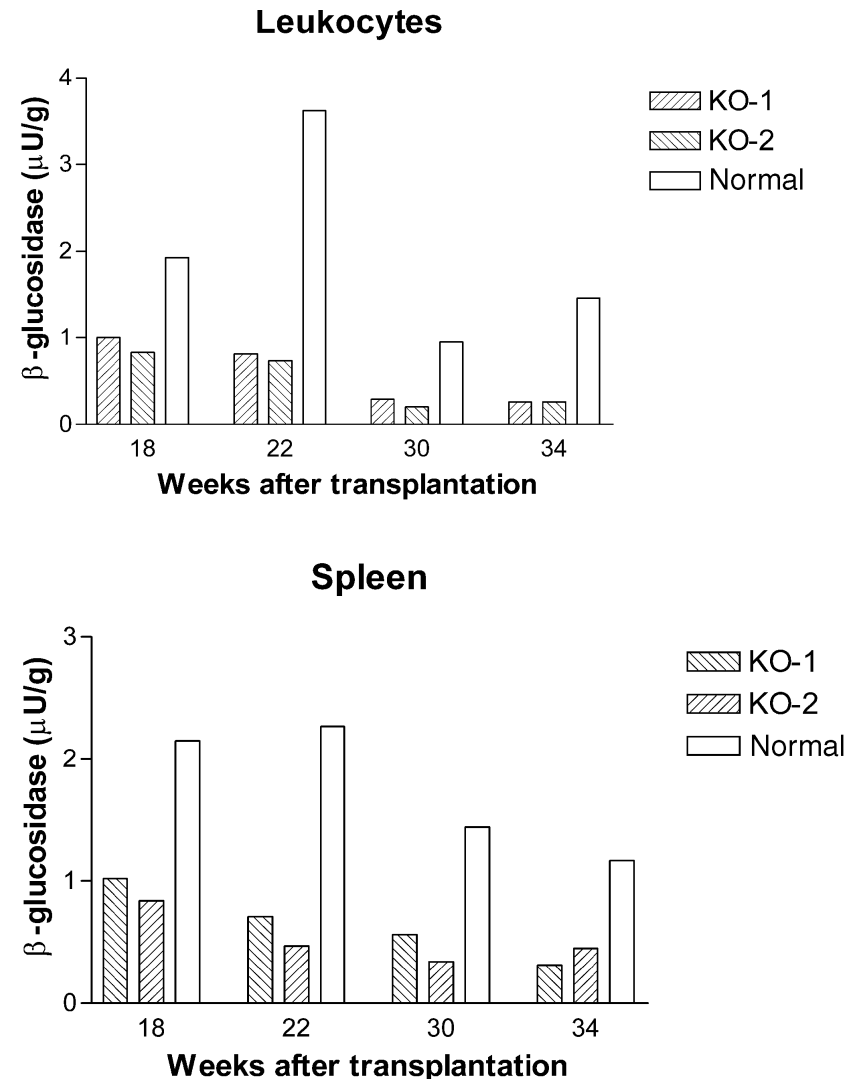

Fig. 1. Spleen and peripheral blood leukocyte acid $\beta$-glucosidase activity of irradiated mice reconstitution after transplantation with hematopoietic stem cells from a fetus homozygous for targeted disruption of the glucocerebrosidase gene (KO-1 and KO-2) or homozygous wild-type fetus hematopoietic stem cells (control) at various time periods after transplantation. Liver acid $\beta$-glucosidase activity was essentially normal (data not shown). This is the expected finding, because hepatocytes are of host type.

stem cells from homozygous wild-type fetuses is shown in Figure 1. It is obvious that the circulating blood cells and the spleen manifest the knockout phenotype. There is no indication of the cell-cell correction that seems to occur with some lysosomal defects such as $\beta$-glucoronidase deficiency (12). The accumulation of glycolipid in the liver and spleen, shown in Figure 2, is much less impressive than the enzyme deficiency. The amount of glycolipid found in the animals that have been transplanted with knockout hematopoietic stem cells is greater than that of controls, but the difference is relatively small. Moreover, there is no evidence that the storage of glycolipid increases with time.

To determine whether we could increase the glucocerebroside burden in mice by exogenous loading with glucocerebroside, we administered a complex of albumin and glucocerebroside intravenously. Preliminary studies (data not shown) indicated that an increase of glycolipid load resulting from a single injection persisted for 2 days. Accordingly, we injected the glucocerebroside/albumin
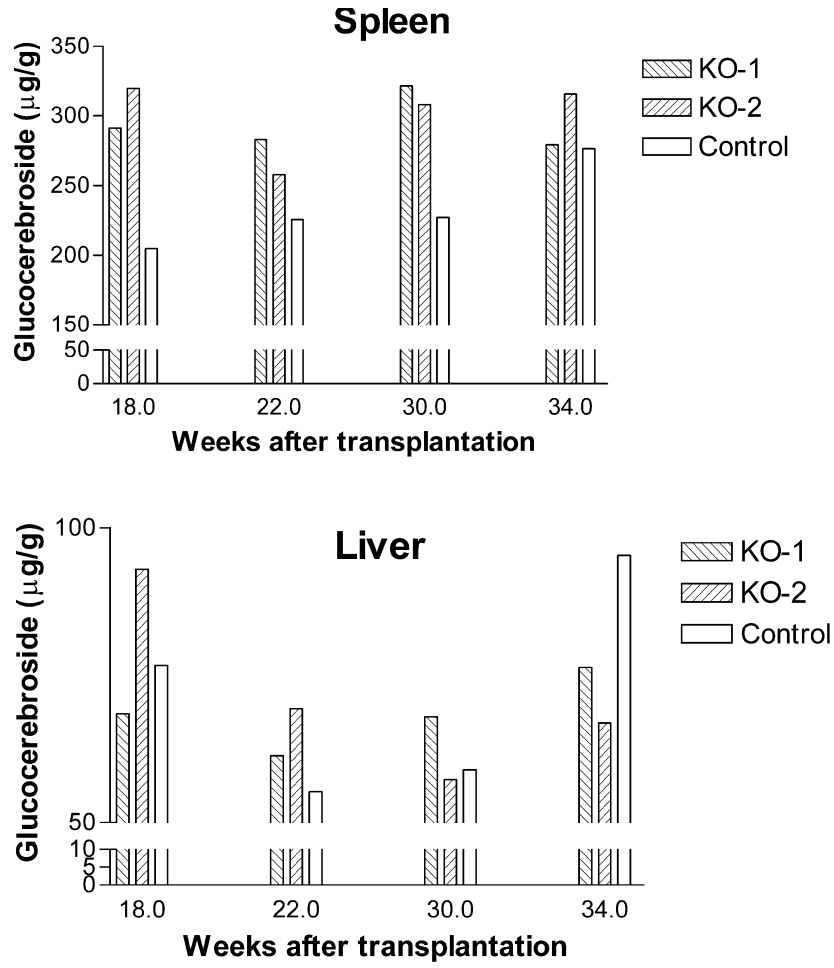

Fig. 2. Spleen and liver glucocerebroside concentration in irradiated mice after reconstitution with hematopoietic stem cells from a fetus homozygous for targeted disruption of the glucocerebrosidase gene (KO-1 and KO-2) or homozygous wild-type fetus hematopoietic stem cells (control) at various time periods after transplantation.

complex daily for 5 days and sacrificed the animals to measure liver glycolipid accumulation 3 days later. The results of this experiment are shown in Figure 3.

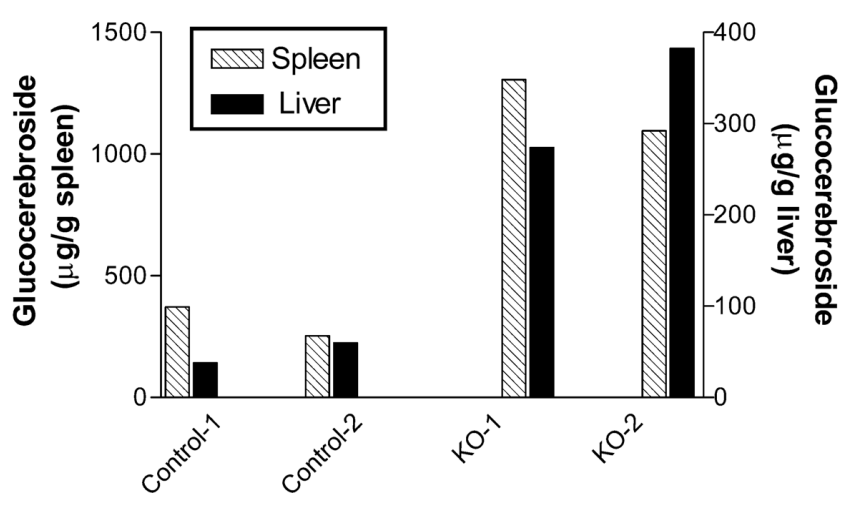

Fig. 3. The effect of repeated glucocerebroside injections on liver and spleen glucocerebrosidase content of mice transplanted with hematopoietic stem cells from a fetus homozygous for targeted disruption of the glucocerebrosidase gene (KO-1 and KO-2) or homozygous wild-type fetus hematopoietic stem cells (control). Each animal received a total of $1122 \mu \mathrm{g}$ of glucocerebroside in five divided doses beginning on day 90 posttransplantation. The animals were sacrificed 3 days after the final dose. Spleen, hatched bars; liver, solid bars. 
The amount of glucocerebroside burden that develops spontaneously or the greater burden that is achieved by exogenous loading falls far short of the 20- to 100-fold increase that has been reported in humans with Gaucher disease (1). In view of this, it is not surprising that we do not see Gaucher cells in the marrow, liver, or spleen; even electron microscopy does not reveal changes typical of human Gaucher disease.

\section{Discussion}

There has been a great need for an animal model of Gaucher disease. Such a model might be useful in providing concrete information of the effect of intervals between enzyme replacement doses and the optimal amount of enzyme that should be given, treatment parameters that have been difficult to establish (13). The efficacy of gene transfer therapy and the use of inhibitors could also be evaluated with a suitable animal model. A naturally occurring canine model of Gaucher disease (14) no longer exists. Knockin and knockout models have not been viable past birth $(6,7,15)$. Glucocerebrosidase inhibitors have been used, but produce a transient model that cannot be used for testing reconstitution $(16,17)$.

The usefulness of this chimeric model of Gaucher disease is impaired by the rather limited amount of glycolipid that is stored in murine macrophages, in spite of the fact that they are very deficient in glucocerebrosidase. This is very likely due to species differences; perhaps other enzymes that exist in higher levels in the mouse and in man or better excretory functions limit the accumulation of glycolipid in this species. Nonetheless, the model may be useful in gene therapy trials and/or enzyme replacement therapy, particularly if greater degrees of loading of macrophages with glucocerebroside can be achieved or sufficiently sensitive histochemical methods are developed to evaluate glycolipid accumulation.

\section{Acknowledgment}

This is manuscript number 14935-MEM from The Scripps Research Institute. Supported by NIH grant RO1HL21544 (HD) and the Stein Endowment Fund.

\section{References}

1. Beutler E, Grabowski G. (2001) Gaucher disease. In Scriver $\mathrm{CR}$, Beaudet AL, Sly WS, Valle D (eds). The Metabolic and Molecular Bases of Inherited Disease. New York: McGraw-Hill; pp. 3635-3668.

2. Barton NW, Brady RO, Dambrosia JM, et al. (1991) Replacement therapy for inherited enzyme deficiency: macrophagetargeted glucocerebrosidase for Gaucher's disease. N. Engl. J. Med. 324: 1464-1470.

3. Kohn DB. (2001) Gene therapy for genetic haematological disorders and immunodeficiencies. J. Intern. Med. 249: 379-390.

4. Cox T, Lachmann R, Hollak C, et al. (2000) Novel oral treatment of Gaucher's disease with N-butyldeoxynojirimycin (OGT 918) to decrease substrate biosynthesis. Lancet 355: 1481-1485.

5. Platt FM, Jeyakumar M, Andersson U, et al. (2001) Inhibition of substrate synthesis as a strategy for glycolipid lysosomal storage disease therapy. J. Inherit. Metab. Dis. 24: 275-290.

6. Tybulewicz VLJ, Tremblay ML, LaMarca ME, et al. (1992) Animal model of Gaucher's disease from targeted disruption of the mouse glucocerebrosidase gene. Nature 357: 407-410.

7. Liu Y, Suzuki K, Reed JD, et al. (1998) Mice with type 2 and 3 Gaucher disease point mutations generated by a single insertion mutagenesis procedure (SIMP). Proc. Natl. Acad. Sci. U.S.A. 95: 2503-2508.

8. Beutler E, Gelbart T, Kuhl W, Sorge J, West C. (1991) Identification of the second common Jewish Gaucher disease mutation makes possible population based screening for the heterozygous state. Proc. Natl. Acad. Sci. U.S.A. 88: 10544-10547.

9. Raghavan SS, Topol J, Kolodny EH. (1980) Leukocyte betaglucosidase in homozygotes and heterozygotes for Gaucher disease. Am. J. Hum. Genet. 32: 158-173.

10. Deguchi H, Fernandez JA, Pabinger I, Heit JA, Griffin JH. (2001) Plasma glucosylceramide deficiency as potential risk factor for venous thrombosis and modulator of anticoagulant protein C pathway. Blood 97: 1907-1914.

11. Barton NW, Rosenberg A. (1975) Metabolism of glucosyl $\left({ }^{3} \mathrm{H}\right)$ ceramide by human skin fibroblasts from normal and glucosyleramidotic subjects. J. Biol. Chem. 250: 3966-3971.

12. Wolfe JH, Sands MS, Barker JE, et al. (1992) Reversal of pathology in murine mucopolysaccharidosis type VII by somatic cell gene transfer. Nature 360: 749-753.

13. Beutler E. (1997) Enzyme replacement therapy for Gaucher disease. Baillieres Clin. Haematol. 10: 711-723.

14. Van De Water NS, Jolly RD, Farrow BRH. (1979) Canine Gaucher disease-the enzymic defect. Aust. J. Exp. Biol. Med. Sci. 57: 551-554.

15. Willemsen R, Tybulewicz V, Sidransky E, et al. (1995) A biochemical and ultrastructural evaluation of the type 2 Gaucher mouse. Mol. Chem. Neuropathol. 24: 179-192.

16. Adachi M, Volk BW. (1977) Gaucher disease in mice induced by conduritol-B-epoxide: morphologic features. Arch. Pathol. Lab. Med. 101: 255-259.

17. Atsumi S, Nosaka C, Iinuma H, Umezawa K. (1993) Accumulation of tissue glucosylsphingosine in Gaucher-like mouse induced by the glucosylceramidase inhibitor cyclophellitol. Arch. Biochem. Biophys. 304: 302-304. 